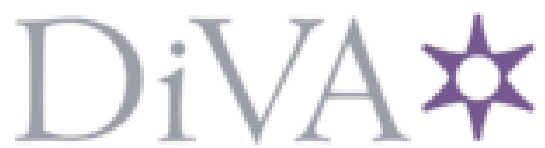

http://www.diva-portal.org

This is the published version of a paper published in Asia Pacific Journal of Marketing and Logistics.

Citation for the original published paper (version of record):

Xin, X., Miao, X., Chen, Q., Shang, T. (2021)

User participation, knowledge management capability and service innovation: ecommerce enterprises in the digital age

Asia Pacific Journal of Marketing and Logistics, ahead-of-print(ahead-of-print) https://doi.org/10.1108/apjml-10-2020-0724

Access to the published version may require subscription.

N.B. When citing this work, cite the original published paper.

Permanent link to this version:

http://urn.kb.se/resolve?urn=urn:nbn:se:kth:diva-304733 


\title{
User participation, knowledge management capability and service innovation: e-commerce enterprises in the digital age
}

\author{
Xiaohua Xin \\ School of Management, Northwestern Polytechnical University, Xi'an, China \\ Xiaoming Miao \\ Northwestern Polytechnical University, Xi'an, China \\ Qian Chen \\ Machine Design Department, ITM, KTH Royal Institute of Technology, \\ Stockholm, Sweden, and \\ Tiantian Shang \\ School of Economics and Management, Xi'an Technological University, Xi'an, China
}

innovation in the digital age

Received 15 October 2020 Revised 5 March 2021 27 May 2021 Accepted 20 June 2021

\begin{abstract}
Purpose - Despite the fact that user participation (UP) has been highlighted as an important aspect in innovation, previous findings on its relationship with service innovation performance (SIP) are inconsistent. This study aims to investigate the relationships among UP, knowledge management capability (KMC) and SIP, especially in the digital age, inspired by the theories of knowledge-based and absorptive capacity.

Design/methodology/approach - Based on a sample of 252 Chinese e-commerce enterprises, this study adopts a hierarchical regression analysis and bootstrap method to test the theoretical framework and research hypotheses.

Findings - UP and KMC have positive effects on SIP, respectively. KMC plays a mediating role in the effect of UP on SIP. Furthermore, the intermediary role of KMC varies in different sub-paths between UP and SIP.

Originality/value - First, this study provides some explanations for inconsistent arguments on the relationship between UP and service innovation. Second, with the consideration of specific dimensions of UP and SIP, the mediation role of KMC varies in different sub-paths has been recognized, which provides a deeper understanding of the relationship between UP and SIP. Third, this study opens the discussion about how to realize SIP more effectively in the digital age, advancing theoretical and practical developments on service innovation.
\end{abstract}

Keywords Service innovation, User participation, Knowledge management capability, E-commerce

Paper type Research paper

\section{Introduction}

Fostering innovation enables service firms to gain a sustainable competitive advantage (Alam and Intekhab, 2010; Dayan and Ndubisi, 2019). Service innovation has recently been highlighted as a key priority in both service research and innovation research (Acharya et al., 2020; Witell et al., 2016). In particular, with the wide integration of digital technology into business, firms face substantial challenges of service innovation management due to the uncertainty of the innovation environment. Nevertheless, the combination of digital technologies and accessed resources (such as knowledge) brings new opportunities for service innovation (Barrett et al., 2015) since digital technologies such as information and

The authors gratefully acknowledge the grant from National Social Science Foundation of China(18BGL033) for financial support.

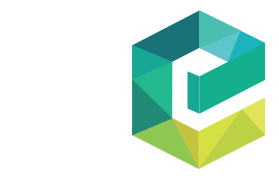

Asia Pacific Journal of Marketing and Logistics ing Limited DOI 10.1108/APJML-10-2020-0724 
communication technologies (ICTs) play a fundamental and transformative role in service innovation (Vargo and Lusch, 2008; Yoo et al., 2012).

To succeed in service innovation, wise and effective collaboration with external organizations and individuals, particularly with users, is needed (Goodman et al., 2017). In the digital age, particularly with the remarkable growth of e-commerce in various industries, great changes have taken place regarding users' information storage and interaction. For example, users have more opportunities to publish and share all kinds of information on the internet, and enterprises are no longer constrained by the high cost of information acquisition and analysis. However, existing literature has mainly focused on the relationship of user participation (UP) and service innovation in both the traditional service industry, i.e. the foodservice industry (Darius et al., 2018) and the tourism industry (Hu et al., 2009) and manufacturing industry with service transformation (Cheng and Krumwiede, 2017; Morgan et al., 2019). However, scant attention has been placed on the influence of UP on service innovation in e-commerce enterprises.

Furthermore, UP has been argued as a potential positive factor on service innovation performance (SIP) in the majority of previous studies (e.g. Bonner and Walker, 2004; Trischler et al., 2018), whereas several studies show that UP might have no positive influence or has a negative influence on service quality or service innovation (e.g. Cheng and Krumwiede, 2012; Ngo and O'cass, 2013). The inconsistent conclusions, to some extent, suggest that there is an unopened "black box" in the influence path of UP on SIP.

In practice, some successful e-commerce enterprises not only focus on acquiring external knowledge through users' information sharing and interactive cooperation but also emphasize the ability to realize the user knowledge to innovation. For example, Alibaba collected user information of "Taobao" through questionnaire surveys and senior product experiencers who were paid highly and then integrated relevant knowledge to launch the "family version of Taobao" successfully. It may be indicated that based on the potential and real needs of users, the strong knowledge management capability (KMC) of enterprises would promote service innovation. According to the knowledge-based theory (Grant, 1996), knowledge base effectively promotes the evolution of enterprise capability, and the degree of capability evolution directly affects the effectiveness and efficiency of service innovation. In other words, $\mathrm{KMC}$ is especially important for enterprises to realize the user knowledge to innovation. However, the role of KMC between UP and SIP has received very limited attention hitherto.

To fill this identified gap, this study explores the relationship among UP, KMC and SIP in the digital age. The remaining sections are organized as follows: the next section reviews the related literature. Then several hypotheses are proposed to construct the conceptual model used in this study. The research method, data analyses and the research results are presented in the subsequent two sections. The final section discusses the results and proposes the theoretical contributions, practical implications, research limitations and future research directions.

\section{Literature review \\ User participation}

UP refers to the users' behavior in the process of using a product or service that enables the enterprise to obtain the information, resources and concrete actions of users (Cermak et al., 1994). Particularly in the e-commerce environment, UP becomes more important for service enterprises (Moon et al., 2017; Ting et al., 2020). Specifically, users not only leave traces in the process of using products or services in the internet era, which can reveal user characteristics and potential needs, but also give evaluation and feedback to products or services anytime and anywhere and even participate in the process of product development. On this basis, UP 
is divided into two dimensions in this study, including information sharing (IS) (Hubbert, 1995) and interactive cooperation (IC) (Ennew and Binks, 1999). In general, IS includes users' personal information, transaction data, choice preferences, consumption habits and star rating, while IC refers to users' feedback on enterprises' products or services, such as suggestions for products, experience sharing on social platforms and participation in the process of service product development.

Given that the user is one of the important co-creation sources, scholars have focused on the importance of UP in the innovation process of a new product or service (e.g. Morgan et al., 2018; Morgan et al., 2019; Wang et al., 2020). Specifically, it notes that there are positive outcomes of UP in terms of value creation, firm performance and service evaluation (e.g. An and Han, 2020; Bae, 2020; Ho et al., 2020). However, the relationship between UP and service innovation outcomes, becoming an important driving force of enterprise development, has received less attention.

\section{Service innovation}

The definition of service innovation is not unified in the existing literature (Paswan et al., 2009; Witell et al., 2016). Some scholars developed Schumpeter's view on service innovation (Gallouj and Savona, 2008; Toivonen and Tuominen, 2009). In their view, recombination innovations are emphasized as central to service innovation, and the high frequency of service innovation is suggested in new firms, while the customer value is not taken into account. Furthermore, Lusch and Nambisan (2015) described the broadened conception of service innovation through a tripartite framework consisting of service ecosystem, service platform and value co-creation.

Furthermore, user satisfaction and loyalty are the subjective response to the quality of service innovation (Vakulenko et al., 2019). On this basis, we highlight users as the driver in service innovation especially for an e-commerce enterprise and thereby conceptualizing the service innovation as the one refers to the transformation of new ideas into new or improved service products to meet the needs of users (Lusch and Nambisan, 2015; Witell et al., 2016). Drawing from this, we regard user performance (USP) as a considerable aspect of SIP in e-commerce enterprise. Besides, financial performance $(\mathrm{FP})$ is an important index to reflect the outcomes of innovation. Moreover, internal operation performance (IOP) should be concerned for the light asset non-manufacturing enterprises. Overall, we consider SIP into three dimensions: USP, FP and IOP. More specifically, USP includes user satisfaction, perceived product quality, user acquisition and user retention; FP shows the profitability of service innovation; IOP measures performance internally, while FP and UP are external to the enterprise (Storey and Kelly, 2001).

\section{Knowledge management capability}

$\mathrm{KMC}$ refers to the dynamic ability of the process of knowledge transferring, knowledge sharing, knowledge acquisition, knowledge application and knowledge innovation (Tiwana, 2000). Sawy et al. (1999) pointed that it is not only important for firms to manage knowledge internally but also equally important to effectively manage external knowledge. Indeed, firms can get numerous benefits, including improving dynamic capabilities (Tseng and Lee, 2014), developing organizational performance (Imran et al., 2017), enhancing innovation (Sun et al., 2020) and decreasing consume response time (Lee et al., 2012) from KMC.

The division of KMC has attracted considerable attention from scholars. For example, Mishra and Bhaskar (2011) established the knowledge management process model of learning organization practice and divided KMC into four stages: knowledge creation, knowledge sharing, knowledge enhancement and knowledge retention. Rahman et al. (2013) divided the KMC into three stages: knowledge acquisition, knowledge application and 
knowledge protection. Relying on the existing literature and the digital environment, we concentrate on dimensions of KMC that include knowledge transfer (KT), knowledge sharing (KS), knowledge integration (KI) and knowledge creation (KC).

\section{Hypothesis development}

User participation and service innovation performance

Service-oriented logic emphasizes the crucial role of users in service-value creation (Witell et al., 2017). In previous studies, users have been recognized as one of important co-creators, and their participation is a fundamental source of firms' competitive advantage (Cabigiosu and Campagnolo, 2019; Hidalgo and D'Alvano, 2014). In particular, with the wide usage of advanced information technology, e-commerce enterprises have access to new innovative ideas through UP and keep innovation consistent with the changing of user demands (Salunke et al., 2013), which potentially affects the SIP. The potential role of UP can be supported by arguments from some scholars. For example, Mario et al. (2018) discovered that UP has a positive impact on SIP in service-providing manufacturing enterprises. Halliday and Trott (2010) emphasized that integrating users in the innovation process is beneficial to firms' innovation performance. Morgan et al. (2018) also showed that users' direct involvement in service-product development has a positive effect on the performance of enterprise services.

Moreover, the absorptive capacity theory posits that absorbing new knowledge makes an organization have greater innovativeness and a higher level of performance than those that do not (Cohen and Levinthal, 1990). In general, enterprises could increase the amount of new knowledge at a low cost through users' IS and IC, which greatly reduces the uncertainty of service innovation and contributes to the market acceptance of innovation results. Carbonell et al. (2009) provided empirical evidence for the impact of UP on operational and market dimensions of new service performance. Therefore, the positive role of UP in terms of IS and IC on the improvement of SIP is argued in this study. As mentioned above, here SIP includes IOP, FP and USP. On the one hand, users' IS provides enterprises with the accurate demand information as innovative sources and directions for service innovation. On the other hand, with the users' IC, enterprises make the final service products more in line with users' expectations, which would improve the users' satisfaction and loyalty (e.g. Brodie et al., 2013), the user perception of product quality and the purchase intention (e.g. Schreier et al., 2012). Furthermore, users' IC affects sales performance (e.g. Melton and Hartline, 2010) and internal operation efficiency (e.g. Mahr et al., 2014) during the innovation process. Hence,

H1. UP is positively related to SIP.

H1a. IS is positively related to IOP.

$H 1 b$. IS is positively related to FP.

H1c. IS is positively related to USP.

H1d. IC is positively related to IOP.

H1e. IC is positively related to $\mathrm{FP}$.

H1f. IC is positively related to USP.

The mediating effect of knowledge management capability

According to the absorptive capacity theory, building a knowledge base is required for organizations to absorb and apply new knowledge. Or, it is equivalent to "shutting out" the development of knowledge and technology, which might bring damage to the organization, 
particularly for its innovation in the future (Schumpeter, 1942). In the digital age, relational learning, especially between users and enterprises, has become the primary source of new knowledge (Weerawardena et al., 2019). Watson et al. (2018) proposed that the relationships with external stakeholders, particularly users, provide firms access to resources outside their boundaries and thus augment the organizational knowledge base. Previous studies have shown that users' IS and IC can promote capabilities of enterprises, such as knowledge transferring (Chang, 2019), knowledge development (Johansson et al., 2019), knowledge integration (Yu, 2017) and knowledge sharing (Wang and Liu, 2019). Therefore, it can be indicated that IS and IC are positively related to KMC.

Furthermore, the enterprises that adopt the knowledge management strategies have a higher level of new service development than those that do not (Storey and Kahn, 2010). The continuous improvement of KMC could promote the penetration speed of external knowledge into the key links of service innovation within enterprises and then promote the transformation of knowledge into service innovation effectively. Aboelmaged (2014) pointed out that $\mathrm{KMC}$ is positively associated with innovation performance. Johansson et al. (2019) also showed that there is a positive relationship between customer knowledge development and SIP. Therefore, it can be indicated that there is a positive influence of KMC on SIP.

Drawing on the knowledge-based theory, the external knowledge obtained by enterprises cannot directly affect enterprise innovation, and it needs to be integrated, transformed and developed to promote the occurrence of innovation (Eisenhardt and Martin, 2000). Furthermore, the SECI model proposed four steps for effective management and utilization of knowledge (Ikujiro, 1998). The steps are acquiring tacit knowledge through interacting with users, transforming tacit knowledge into explicit knowledge through knowledge sharing, systematizing explicit knowledge through knowledge integration and translating explicit knowledge into concrete measures through the creation and then the act. On this basis, it can be argued that KMC plays a critical role in enhancing the positive effects of external knowledge provided through IS and IC on enterprise innovation. The perfection of $\mathrm{KMC}$ enhances the possibility and effectiveness of transforming external knowledge into innovative achievements, including IOP, FP and USP. If there is no perfect knowledge management mechanism, the resources will be wasted, and even IOP will be affected, and then USP and FP will be affected (Foss et al., 2011). Therefore, the research hypotheses are

H2. KMC plays a mediating role between UP and SIP.

H2a. KMC plays a mediating role between IS and IOP.

$H 2 b$. KMC plays a mediating role between IS and FP.

H2c. KMC plays a mediating role between IS and USP.

H2d. KMC plays a mediating role between IC and IOP.

H2e. KMC plays a mediating role between IC and FP.

H2f. KMC plays a mediating role between IC and USP.

By above analysis, we propose the conceptual model in this study, as shown in Figure 1.

\section{Research design and methods \\ Sample and data collection}

China is one of the most promising emerging economies, and e-commerce enterprises in China have been rising rapidly. The samples were Chinese e-commerce enterprises that include traditional e-commerce enterprises and Internet-based enterprises. A structured 


\section{APJML}

Figure 1.

Conceptual model
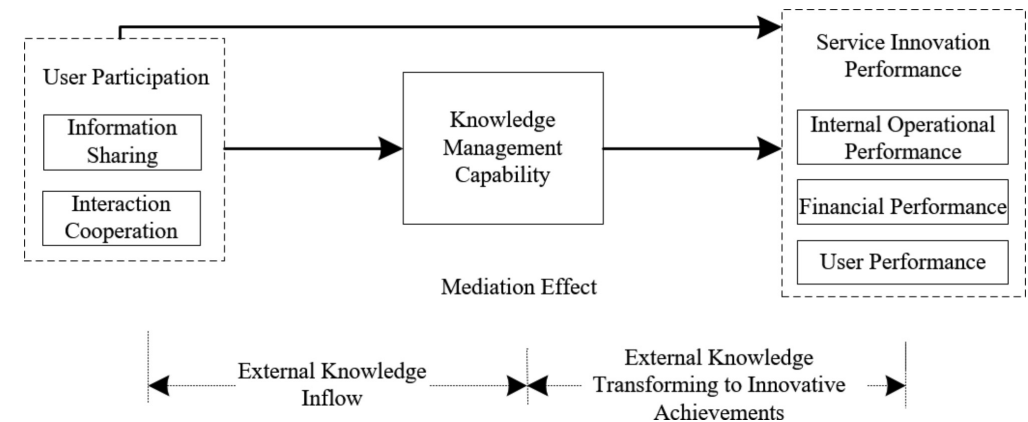

Achievements

questionnaire survey was conducted. The measurement scales were developed based on the existing literature and interviews with managers. First, we developed an English version of the measurement scales based on a thorough review of relevant literature, and then we translated them into Chinese by three scholars who have research experience abroad. Second, we refined the measurement scales based on in-depth interviews during the pilot test stage. Next, the items were modified after conducting a pre-test with 23 senior managers from the EMBA programs. Finally, the formal questionnaire was formed after discussing it with three professors in the field of innovation management.

In this study, a total of 400 questionnaires were distributed in three ways to test the relationship among UP, KMC and SIP at the organizational level. First, we contacted the senior managers of typical and well-known 28 e-commerce enterprises in China through our family and friends. These enterprises include B2B e-commerce enterprises (e.g. Alibaba, Global Sources and Toocle), life service e-commerce enterprises (e.g. Eleme, DiDi and Ctrip), retail e-commerce enterprises (e.g. Tmall, JD and Suning) and cross border e-commerce enterprises (e.g. Ymatou). Second, we invited 62 senior and mid-level managers of e-commerce enterprises from MBA and EMBA classes to answer the questionnaire. Third, the "Questionnaire Star (QS)" platform (the most widely used approach to collect survey data in China) was used to distribute 310 questionnaires. In total, 323 questionnaires were received, of which 252 were valid, with an effective response rate of $63.0 \%$. Table 1 displays sample characteristics.

\section{Variables and measures}

In this study, each item of the survey questionnaire was rated by using a five-point Likert scale. For example, "1" represents "totally disagree" and " 5 " represents "totally agree" The construct of UP was measured with IS and IC dimensions with 10 items adapted from Claycomb et al. (2001). KMC was measured with KT, KS, KI and KC dimensions by using 13 items adapted from Tiwana (2000) and $\mathrm{Wu}$ (2014). The measurement of SIP was based on the scale developed by Storey and Kelly (2001) and referred to the scales of Joe and Hull (2003), consisting of seven items from IOP, FP and USP dimensions.

Besides, this study controlled for firm type, firm sale, firm age and frequency of service innovation that might have confounding effects on SIP (Li et al., 2019; Schaarschmidt et al., 2018). For the above four control variables, we converted them into dummy variables firstly in order to make the regression model more scientific and accurate (Table 2).

\section{Common method variance}

This study adopted the procedural and statistical remedial methods to reduce CMV (Podsakoff et al., 2003). Procedurally, questions of the questionnaire were organized by 


\begin{tabular}{|c|c|c|c|c|}
\hline Characteristics of the respondents & Indicator description & Frequency & $\%$ of respondents & Service \\
\hline \multirow[t]{3}{*}{ Firm ownership } & State-owned & 58 & 23.02 & the digital age \\
\hline & Private & 179 & 71.03 & \\
\hline & International joint venture & 15 & 5.95 & \\
\hline \multirow[t]{7}{*}{ Firm type (multiple choice questions) } & $\mathrm{B} 2 \mathrm{~B}$ & 147 & 58.24 & \\
\hline & $\mathrm{B} 2 \mathrm{C}$ & 144 & 57.14 & \\
\hline & B2G & 14 & 5.49 & \\
\hline & $\mathrm{C} 2 \mathrm{C}$ & 42 & 16.79 & \\
\hline & $\mathrm{C} 2 \mathrm{~B}$ & 19 & 7.49 & \\
\hline & $\mathrm{O} 2 \mathrm{O}$ & 36 & 14.29 & \\
\hline & Others & 14 & 5.38 & \\
\hline \multirow[t]{3}{*}{ Firm age } & $<10$ & 27 & 10.71 & \\
\hline & $10-30$ & 183 & 72.62 & \\
\hline & $>30$ & 42 & 16.67 & \\
\hline \multirow[t]{3}{*}{ Employee number } & $<1000$ & 39 & 15.48 & \\
\hline & $1000-10,000$ & 72 & 28.57 & \\
\hline & $>10,000$ & 141 & 55.95 & \\
\hline \multirow[t]{3}{*}{ Position in the company } & Senior managers & 171 & 67.86 & \\
\hline & Middle managers & 78 & 30.95 & \\
\hline & Staff of service development & 3 & 1.19 & Table 1 \\
\hline \multicolumn{5}{|c|}{ Note(s): proportion of enterprise type $=$ number of times the option is selected/number of valid questionnaires Sample characteristics } \\
\hline
\end{tabular}

\begin{tabular}{|c|c|c|c|c|}
\hline \multirow[t]{2}{*}{ Primitive variables } & & \multicolumn{2}{|c|}{ Dummy variables } & \\
\hline & & D11 & D12 & \\
\hline \multirow[t]{4}{*}{ Firm type } & State-owned enterprise & 0 & 0 & \\
\hline & Private enterprise & 1 & 0 & \\
\hline & International joint venture & 0 & 1 & \\
\hline & & D21 & $\mathrm{D} 22$ & \\
\hline \multirow[t]{4}{*}{ Firm age } & Within 10 years & 0 & 0 & \\
\hline & 10-30 years & 1 & 0 & \\
\hline & More than 30 years & 0 & 1 & \\
\hline & & D31 & D32 & \\
\hline \multirow[t]{4}{*}{ Firm scale } & Less than 1000 people & 0 & 0 & \\
\hline & 1000-10,000 people & 1 & 0 & \\
\hline & More than 10,000 people & 0 & 1 & \\
\hline & & D41 & D42 & \\
\hline \multirow[t]{3}{*}{ Frequency of service innovation } & Lower & 0 & 0 & Table 2. \\
\hline & General & 1 & 0 & Virtual variable \\
\hline & Higher & 0 & 1 & settings \\
\hline
\end{tabular}

mixing items of each variable together with items of the other variables. In addition, the respondents' anonymity was ensured. Statistically, Harman's single-factor test was adopted. The results show that the first factor explained 44.905\%, less than 50\% (Chumg et al., 2016), indicating that no single factor accounted for the majority of the variance. Furthermore, there are no especially high (i.e. >0.9) correlations between any variables (Pavlou et al., 2007). Hence, CMV is not a problem in this study.

\section{Date analysis and results}

Reliability and validity

Reliability. As shown in Table 3, the Cronbach's $\alpha$ values are greater than 0.7 , indicating strong reliability (Hair et al., 2010). Moreover, to be considered reliable, construct reliability 


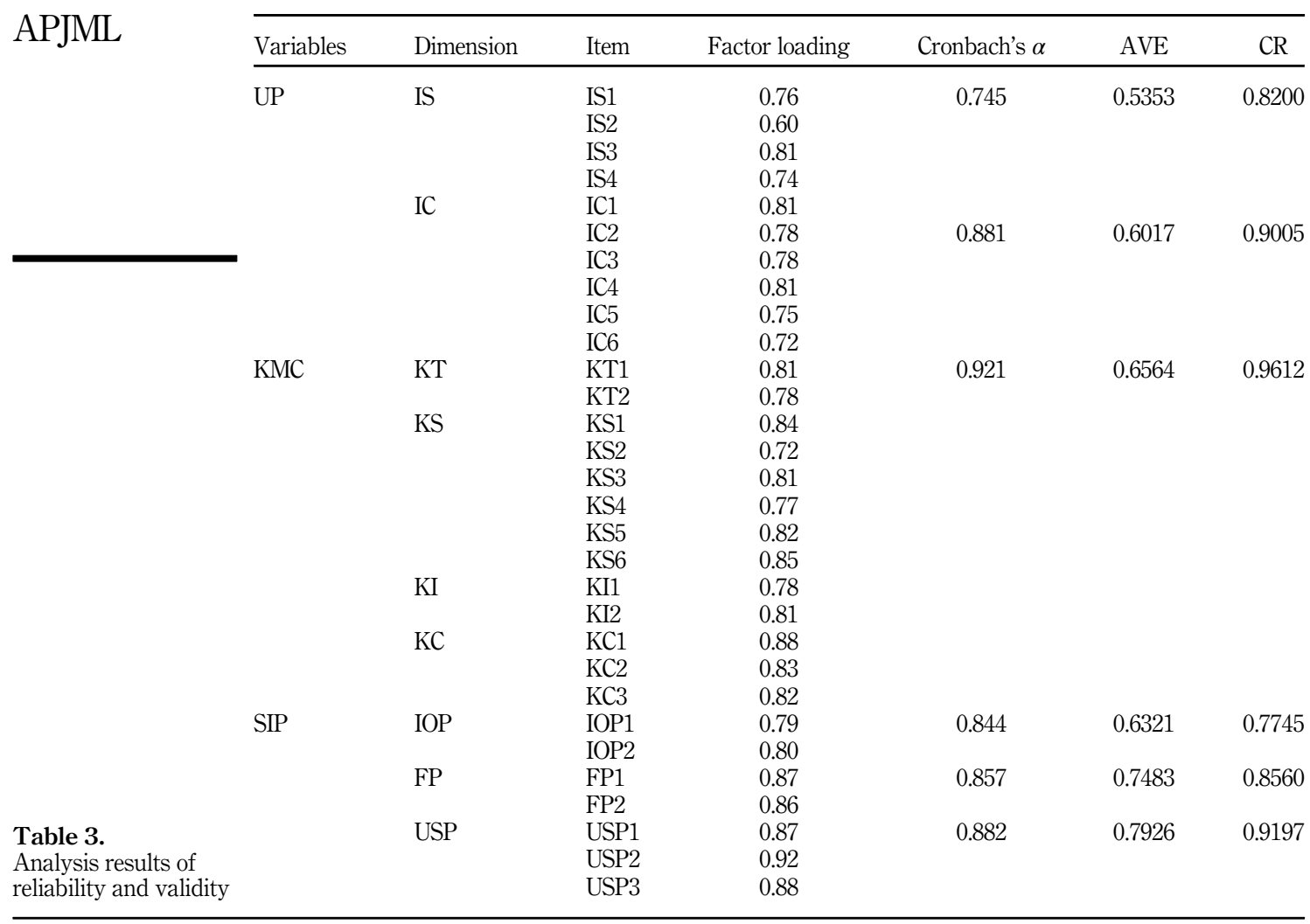

(CR) must be over 0.6 (Feng et al., 2016). We calculated CR values based on the values of standardized factor loading. The results show that $\mathrm{CR}$ values of all variables are higher than 0.774, demonstrating that the internal consistency of the constructs is better.

Validity. First, to ensure content validity, we adopted measurement items from prior research, conducted interviews with managers and professors and carried out a pre-survey to amend items. Second, exploratory factor analysis with maximum variance rotation was conducted to examine construct validity. The results show that factor loadings for all latent variables are greater than 0.6 and significant, demonstrating the acceptable construct validity (Nunnally, 1978). Moreover, we applied confirmatory factor analysis to assess construct validity. The results demonstrate a highly appropriate model fit and fulfilled the criteria proposed by Hair et al. $(2010): \chi^{2} / \mathrm{df}=2.551, \mathrm{GFI}=0.852, \mathrm{IFI}=0.921, \mathrm{CFI}=0.919$, $\mathrm{NFI}=0.876$, TLI $=0.882$ and $\mathrm{RMSEA}=0.079$. Third, the average variance extracted (AVE) values of variables are higher than 0.5 , which indicates that the research variables have good convergent validity (Flynn et al., 2010). Furthermore, the square roots of AVE are greater than the correlation coefficients of each construct (Table 4), which indicates the good discriminant validity (Fornell and Larcker, 1981).

Hypotheses testing

Before examining research hypotheses, the means, standard deviations and correlation of all variables were calculated. As displayed in Table 4, the results of correlation analysis are 


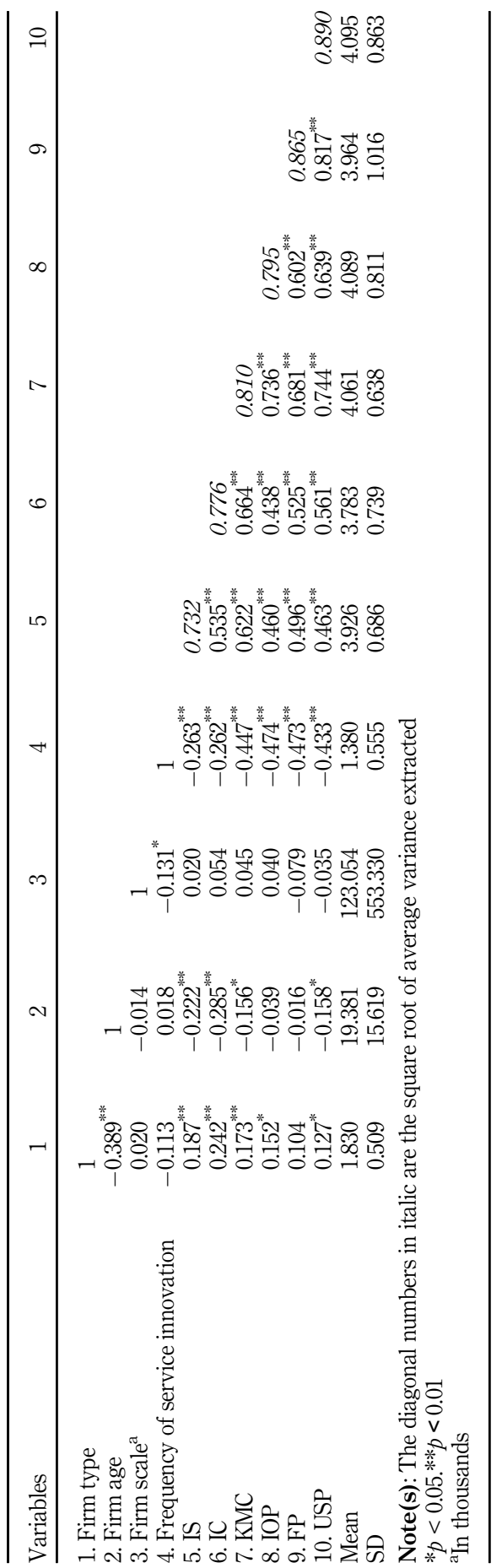

Service innovation in the digital age 
consistent with the direction of the hypotheses, which provides preliminary evidence for confirming the hypotheses.

Main effects. We applied hierarchical regression analyses to test the hypotheses (Li et al., 2019; Son and Jin, 2019). First, all the control variables were added to the regression equation to test their effects on SIP and KMC, respectively. Then IS and IC were introduced as the independent variable into the regression equation to test the effects of the variables on the SIP and $\mathrm{KMC}$, respectively (Table 5).

Table 5 contains the regression results. From model 1 to model 3 , the dependent variable is SIP, while the dependent variable is KMC in model 4 and model 5. In model 1, SIP is regressed on all control variables. Model 2 includes all control variables and independent variables. Here, IS is positively associated with $\operatorname{SIP}(\beta=0.288, p<0.01)$, and IC is positively related to $\operatorname{SIP}(\beta=0.321, p<0.01)$ in support of $H 1$. Model 3 includes all control variables and mediating variables, and the results show that $\mathrm{KMC}$ has a positive effect on $\operatorname{SIP}(\beta=0.721, p<0.01)$. In model 5 , IS $(\beta=0.328, p<0.01)$ and IC $(\beta=0.399, p<0.01)$ have positive effects on KMC.

Mediation effects. We used two methods to test the mediation hypotheses. First, we considered the causal steps approach (Baron and Kenny, 1986) to test our mediating hypotheses. Besides, the Bootstrap procedure with 1,000 bootstrap samples was utilized to test the significance of mediating effects again (Preacher and Hayes, 2008). The test results are shown in Tables 6 and 7.

We take the intermediary role of KMC between IS and IOP as an example to explain. IS has a significant positive effect on IOP $(\beta=0.460, p<0.001)$. But after KMC is included in the regression equation, the influence of IS on IOP is no longer significant $(\beta=0.004, p<0.05)$, while KMC still has a significant positive effect on IOP $(\beta=0.733, p<0.001)$. The results indicate that KMC plays a complete intermediary role between IS and IOP. Thus, $H 2 a$ is supported.

After incorporating $\mathrm{KMC}$ in the influence path of IS on FP, the results show that $\mathrm{KMC}$ has a significant positive effect on $\mathrm{FP}(\beta=0.609, p<0.001)$, while the positive effect of IS on FP is

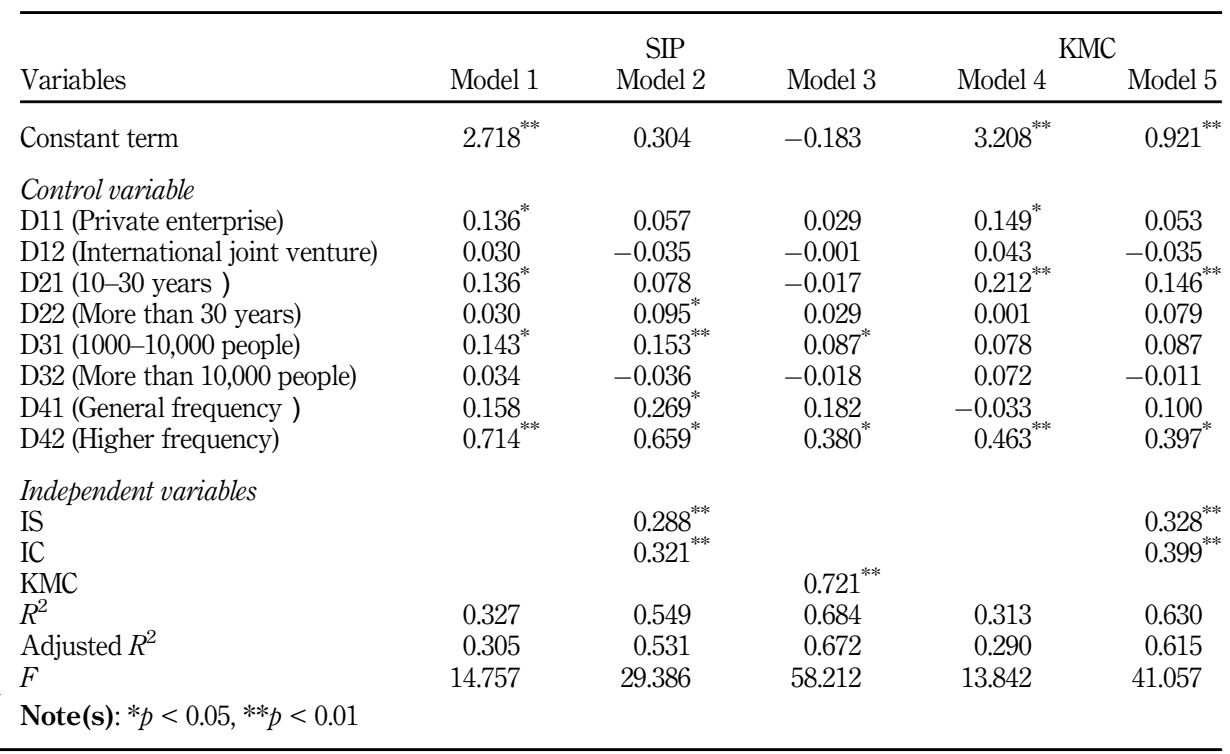

Table 5.

Results of hierarchical linear regression model with control variables 
significantly reduced $(\beta=0.117, p<0.05)$. The results indicate that $\mathrm{KMC}$ plays a part in the intermediary role between IS and FP. Hence, $H 2 b$ is partially supported.

After incorporating KMC in the influence path of IS on USP, the results show that KMC has a significant positive effect on USP $(\beta=0.745, p<0.001)$, while IS has no significant positive effect on USP $(\beta=0.001, p>0.05)$. This shows that KMC plays a fully mediating role in the relation between IS and USP. Hence, $H 2 c$ is supported.

For the influence path of IC on IOP, after incorporating $\mathrm{KMC}$ into the regression equation, the results show that $\mathrm{KMC}$ has a significant positive effect on IOP $(\beta=0.796, p<0.001)$, while IC no longer has a significant positive effect on IOP $(\beta=-0.091, p>0.05)$, which indicates that KMC acts fully intermediary between IC and IOP. Thus, $H 2 d$ is supported.

For the influence path of $\mathrm{IC}$ on $\mathrm{FP}$, after incorporating $\mathrm{KMC}$ into the regression equation, the results show that the positive effect of $\mathrm{KMC}$ on $\mathrm{FP}$ is significant $(\beta=0.595, p<0.001)$, while the positive effect of IC on FP is significantly reduced $(\beta=0.130, p<0.05)$, which indicates that $\mathrm{KMC}$ plays a part in the intermediary role between IC and FP. Hence, H2e is partially supported.

For the influence path of IC on USP, after incorporating $\mathrm{KMC}$ into the regression equation, $\mathrm{KMC}$ has a significant positive effect on $\operatorname{USP}(\beta=0.665, p<0.001)$, while the positive effect of IC on USP is significantly reduced $(\beta=0.120, p<0.05)$, which indicates that KMC plays a partial intermediary role in the relation between IC and USP. Hence, H2f is partially supported.

Furthermore, the test results of the mediation of KMC by the bootstrapping approach show that the intermediate effects of KMC in six influence paths do not contain zero under the $99 \%$ confidence interval, which further support H2. In addition, the hypothesis H1a, H1b, H1c, H1d, H1e and H1f are supported in the causal steps approach (Tables 6 and 7).

\begin{tabular}{lccccrr}
\hline & $N 1$ & $N 2$ & $N 3$ & $N 4$ & \multicolumn{1}{c}{$N 5$} & \multicolumn{1}{c}{$N 6$} \\
Variables & IOP & IOP & FP & FP & USP & USP \\
\hline IS & $0.460^{* * * *}$ & 0.004 & $0.496^{* * * *}$ & $0.117^{*}$ & $0.463^{* * * *}$ & 0.001 \\
KMC & \multicolumn{2}{c}{$0.733^{* * * *}$} & & $0.609^{* * *}$ & & $0.745^{* * *}$ \\
Indirect effect [LLCI, ULCI] & $0.01[0.4049,0.6787]$ & $0.01[0.3901,0.7465]$ & $0.01[0.3963,0.7706]$ \\
Adjusted $R^{2}$ & 0.209 & 0.538 & 0.243 & 0.469 & 0.211 & 0.551 \\
$F$ & 67.243 & 146.898 & 81.445 & 111.672 & 68.184 & 154.803 \\
Sig & 0.000 & 0.000 & 0.000 & 0.000 & 0.000 & 0.000
\end{tabular}

Note(s): LLCI = lower limit confidence interval; ULCI = upper limit confidence interval $* p<0.05, * * p<0.01, * * * p<0.001$

innovation in the digital age
Table 6.

The mediating effect of KMC on IS and SIP

\begin{tabular}{|c|c|c|c|c|c|c|}
\hline Variables & $\begin{array}{l}N 7 \\
\text { IOP }\end{array}$ & $\begin{array}{l}N 8 \\
\text { IOP }\end{array}$ & $\begin{array}{l}N 9 \\
\text { FP }\end{array}$ & $\begin{array}{c}N 10 \\
\text { FP }\end{array}$ & $\begin{array}{l}N 11 \\
\text { USP }\end{array}$ & $\begin{array}{l}N 12 \\
\text { USP }\end{array}$ \\
\hline $\mathrm{IC}$ & \multirow[t]{2}{*}{$0.438^{* * *}$} & -0.091 & \multirow[t]{2}{*}{$0.525^{\text {**** }}$} & $0.130^{*}$ & \multirow[t]{2}{*}{$0.561^{* * *}$} & $0.120^{*}$ \\
\hline KMC & & $0.796^{* * * *}$ & & $0.595^{* * * *}$ & & $0.665^{* * * *}$ \\
\hline Indirect effect [LLCI, ULCI] & \multicolumn{2}{|c|}{$0.01[0.4064,0.7953]$} & \multicolumn{2}{|c|}{$0.01[0.3594,0.7434]$} & \multicolumn{2}{|c|}{$0.01[0.3473,0.7250]$} \\
\hline Adjusted $R^{2}$ & 0.188 & 0.542 & 0.276 & 0.474 & 0.312 & 0.559 \\
\hline$F$ & 59.226 & 149.634 & 95.086 & 112.126 & 114.897 & 159.922 \\
\hline Sig & 0.000 & 0.000 & 0.000 & 0.000 & 0.000 & 0.000 \\
\hline
\end{tabular}

Note(s): LLCI = lower limit confidence interval; ULCI = upper limit confidence interval $* p<0.05, * * p<0.01, * * * p<0.001$

Table 7.

The mediating effect of $\mathrm{KMC}$ on IC and SIP 
As we all know, the development of ICTs has brought substantial changes to the service industry. Since UP is playing an especially important role in the progress of service innovation, this study focuses on the influence of UP on SIP with the KMC taken into account. Taking Chinese e-commerce firms as a sample, this study draws on the knowledge-based theory and absorptive capacity theory and uses hierarchical regression analysis to explore the impact of UP on SIP in terms of KMC as a mediator. We divide UP into IS and IC and classify SIP into IOP, USP as well as FP to reveal the influence mechanism of UP on SIP. Findings in this study are highlighted in the following points.

Firstly, we found that UP has a positive effect on SIP, and interestingly, IC has a greater impact than IS on SIP. This conclusion is consistent with the finding of Mario et al. (2018), but it is different from the conclusion that there is a negative correlation between UP and firm performance (Ngo and O'cass, 2013). The reason may be the difference between the background of the times and the object of study. With the development of digital technology and ICTs, the convenience and universality of UP are greatly improved. E-commerce enterprises can make use of technological advantages to enable users to participate in multichannel where a large number of user information and creative sources are likely to be captured for enterprise service innovation.

Secondly, KMC plays a mediating role between UP and SIP. Empirical results show that UP affects the KMC and improves the SIP through knowledge transfer, knowledge sharing, knowledge integration and knowledge creation. The conclusion supports the views of Wang and Liu (2019), Aboelmaged (2014) and Foss et al. (2011).

Finally, the degree of mediation effect of KMC varies in different sub-paths. Among them, $\mathrm{KMC}$ plays a complete intermediary role in the influence path of IS on IOP, IS on USP and IC on IOP. The difference is that KMC plays a part of the intermediary role in the influence path of IS on FP, IC on FP and IC on USP. The results show that knowledge acquired through users' IS requires a knowledge management process to fully transform into IOP and USP, while the transformation of FP can be achieved through KMC as well as directly through IS. For the relationship among IC, KMC and SIP, the influence of information obtained through IC on the IOP is entirely achieved through KMC, and the influence of IC on USP and FP can be achieved directly or indirectly through the mediating role of $\mathrm{KMC}$.

\section{Theoretical contributions}

The theoretical contributions of this study mainly include the following aspects. Firstly, the existing literature on service innovation has paid little attention to information redundancy caused by UP in the digital age and fallen short of considering the role of KMC in the transformation of UP into service innovation. This study examined the relationship between UP, KMC and SIP in the context of e-commerce, which enriches the antecedents of SIP. Furthermore, based on the knowledge-basic theory and absorptive capacity theory, this study explored the influence mechanism of UP on SIP by taking KMC as a mediator, which provides some explanations for existing inconsistent conclusions about the effect of UP on SIP (Bonner and Walker, 2004; Ngo and O'cass, 2013; Trischler et al., 2018). Perhaps most notably, we considered specific dimensions of UP and SIP and further found the mediation role of KMC varies in different sub-paths. Our results produce a deeper understanding of the relationship between UP and SIP. Last but not least, ICTs and digital technologies have become important resources of service innovation, which make great changes between service innovation in the digital age and traditional service innovation. However, the existing literature on service innovation has mainly focused on the traditional service industry (Darius et al., 2018; Hu et al., 2009) and serviced manufacturers (Cheng and Krumwiede, 2017; Morgan et al., 2019). Research about the effect of different UP on SIP in the e-commerce industry, 
especially in the digital age, has not been done yet. This study makes an important contribution by filling this void.

\section{Practical implications}

This study also has some practical implications. First, the results suggest UP has a positive effect on SIP, and the positive effect of IC on SIP is higher than that of IS on SIP. Hence, in order to foster service innovation, e-commerce enterprises should pay attention to the participation of existing users and take user information as an important resource to enhance the innovation ability of enterprises. Moreover, e-commerce enterprises should set up public opinion departments to encourage users to actively provide their opinions and suggestions on services to enterprises and even participate in the process of service innovation personally so as to improve the success rate of service innovation.

Second, this study reveals that KMC plays an intermediary role between UP and SIP. This highlights the importance of $\mathrm{KMC}$ in service innovation. To maximize the value of information obtained through UP, e-commerce enterprises should construct a knowledgeoriented enterprise culture aiming for improving the user experience, coordinate the continuous organizational learning of various departments and promote business process optimization and knowledge innovation. Besides, e-commerce enterprises should apply advanced data analysis technology to integrate and utilize knowledge. It is important to promote internal and external knowledge into innovation performance and establish a competitive advantage that is not easy to be imitated.

\section{Limitations and future research directions}

This research has some limitations that provide opportunities for future research. First, we used self-reported subjective data in each firm. Although we took steps to reduce CMV issues, CMV problems could not be eliminated completely. Future research could use the longitudinal research design of multi-time data sources to confirm our findings. Second, only e-commerce enterprises in China were investigated. Even though these enterprises are outstanding, there are also numerous excellent e-commerce enterprises in other countries. Future research should investigate the proposed model by using data collected from other countries. Third, this study examined the intermediary effect of KMC, but some environmental factors (e.g. corporate culture and innovation climate) may also affect the relationship between UP and SIP. Future research, therefore, could examine whether and how environmental factors moderate the impact of UP on SIP.

\section{References}

Aboelmaged, M.G. (2014), "Linking operations performance to knowledge management capability: the mediating role of innovation performance", Production Planning and Control, Vol. 25 No. 1, pp. 44-58.

Acharya, C., Ojha, D., Patel, P.C. and Gokhale, R. (2020), "Modular interconnected processes, fluid partnering, and innovation speed: a loosely coupled systems perspective on B2B service supply chain management”, Industrial Marketing Management, Vol. 89, pp. 209-219.

Alam and Intekhab (2010), "Does service innovation process differ across cultures?", Asia Pacific Journal of Marketing and Logistics, Vol. 22 No. 4, pp. 460-472.

An, M.A. and Han, S.L. (2020), "Effects of experiential motivation and customer engagement on customer value creation: analysis of psychological process in the experience-based retail environment", Journal of Business Research, Vol. 120, pp. 389-397.

Bae, B.R. (2020), "Effects of service authenticity, customer participation and customer-perceived service climate on customers' service evaluation", Asia Pacific Journal of Marketing and Logistics, Vol. 33 No. 5, pp. 1239-1254. 
Baron, R.M. and Kenny, D.A. (1986), "The moderator-mediator variable distinction in social psychological research: conceptual, strategic, and statistical considerations", Journal of Personality and Social Psychology, Vol. 51 No. 6, p. 1173.

Barrett, M., Davidson, E., Prabhu, J. and Vargo, S.L. (2015), "Service innovation in the digital age: key contributions and future directions", Mis Quarterly, Vol. 39 No. 1, pp. 135-154.

Bonner, J.M. and Walker, O.C. Jr (2004), "Selecting influential business-to-business customers in new product development: relational embeddedness and knowledge heterogeneity considerations", Journal of Product Innovation Management, Vol. 21 No. 3, pp. 155-169.

Brodie, R.J., Ilic, A., Juric, B. and Hollebeek, L. (2013), "Consumer engagement in a virtual brand community: an exploratory analysis", Journal of Business Research, Vol. 66 No. 1, pp. 105-114.

Cabigiosu, A. and Campagnolo, D. (2019), "Innovation and growth in KIBS: the role of clients' collaboration and service customization", Industry and Innovation, Vol. 26 No. 5, pp. 592-618.

Carbonell, P., Rodriguez-Escudero, A.I. and Pujari, D. (2009), "Customer involvement in new service development: an examination of antecedents and outcomes", Journal of Product Innovation Management, Vol. 26, pp. 536-550.

Cermak, D.S., File, K.M. and Prince, R.A. (1994), "Customer participation in service specification and delivery", Journal of Applied Business Research, Vol. 10 No. 2, pp. 90-100.

Chang, W. (2019), "The joint effects of customer participation in various new product development stages", European Management Journal, Vol. 37 No. 3, pp. 259-268.

Cheng, C.C. and Krumwiede, D. (2012), "The role of service innovation in the market orientation -new service performance link-age", Technovation, Vol. 32 Nos 7-8, pp. 487-497.

Cheng, C.C.J. and Krumwiede, D. (2017), "What makes a manufacturing firm effective for service innovation? The role of intangible capital under strategic and environmental conditions", International Journal of Production Economics, Vol. 193, pp. 113-122.

Chumg, H.F., Seaton, J., Cooke, L. and Ding, W.Y. (2016), "Factors affecting employees' knowledgesharing behaviour in the virtual organisation from the perspectives of well-being and organisational behavior", Computers in Human Behavior, Vol. 64, pp. 432-448.

Claycomb, C., Lengnick-Hall, C.A. and Inks, L.W. (2001), "The customer as a productive resources: a pilot study and strategic implications", Journal of Business Strategies, Vol. 18 No. 1, pp. 47-68.

Cohen, W.M. and Levinthal, D.A. (1990), "Absorptive capacity: a new perspective on learning and innovation”, Administrative Science Quarterly, Vol. 35 No. 1, pp. 128-152.

Darius, P., Risto, R., Mika, W. and Matti, M. (2018), "Harnessing user innovation for social media marketing: case study of a crowdsourced hamburger", International Journal of Information Management, Vol. 43, pp. 319-327.

Dayan, M. and Ndubisi, N.O. (2019), "B2B service innovation and global industrial service management", Industrial Marketing Management, Vol. 89, pp. 140-142.

Eisenhardt, K.M. and Martin, J.A. (2000), "Dynamic capabilities: what are they?”, Strategic Management Journal, Vol. 21 Nos 10-11, pp. 1105-1121.

Ennew, C.T. and Binks, M.R. (1999), "Impact of participative service relationships on quality, satisfaction and retention: an exploratory study", Journal of Business Research, Vol. 46 No. 2, pp. 121-132.

Feng, T.W., Cai, D., Wang, D. and Zhang, X.D. (2016), "Environmental management systems and financial performance: the joint effect of switching cost and competitive intensity", Journal of Cleaner Production, Vol. 113, pp. 781-791.

Flynn, B.B., Huo, B. and Zhao, X. (2010), "The impact of supply chain integration on performance: a contingency and configuration approach", Journal of Operations Management, Vol. 28 No. 1, pp. 58-71.

Fornell, C. and Larcker, D.F. (1981), "Evaluating structural equation models with unobservable variables and measurement error", Journal of Marketing Research, Vol. 18 No. 1, pp. 39-50. 
Foss, N.J., Laursen, K. and Pedersen, T. (2011), "Linking customer interaction and innovation: the mediating role of new organizational practices”, Organization Science, Vol. 22 No. 4, pp. 980-999.

Gallouj, F. and Savona, M. (2008), "Innovation in services: a review of the debate and a research agenda", Journal of Evolutionary Economics, Vol. 19 No. 2, pp. 149-172.

Goodman, J., Korsunova, A. and Halme, M. (2017), "Our collaborative future: activities and roles of stakeholders in sustainability-oriented innovation", Business Strategy and the Environment, Vol. 26 No. 6, pp. 731-753.

Grant, R.M. (1996), “Toward a knowledge-based theory of the firm”, Strategic Management Journal, Vol. 17 No. S2, pp. 109-122.

Hair, J.F., Black, W.C., Babin, B.J. and Anderson, R.E. (2010), Multivariate Data Analysis, 7th ed., Prentice-Hall, Englewood Cliffs, NJ.

Halliday, S. and Trott, P. (2010), "Relational, interactive service innovation: building branding competence”, Marketing Theory, Vol. 10 No. 2, pp. 144-160.

Hidalgo, A. and D'Alvano, L. (2014), "Service innovation: inward and outward related activities and cooperation mode", Journal of Business Research, Vol. 67 No. 5, pp. 698-703.

Ho, M.H.W., Chung, H.F., Kingshott, R. and Chiu, C.C. (2020), "Customer engagement, consumption and firm performance in a multi-actor service eco-system: the moderating role of resource integration", Journal of Business Research, Vol. 121, pp. 557-566.

Hu, M.L.M., Horng, J.S. and Sun, Y.H.C. (2009), "Hospitality teams: knowledge sharing and service innovation performance", Tourism Management, Vol. 30 No. 1, pp. 41-50.

Hubbert, A.R. (1995), Customer Co-creation of Service Outcomes: Effects of Locus of Causality Attributions, Unpublished doctoral dissertation, Arizona State University.

Ikujiro, N. (1998), The Knowledge-Creating Company, Oxford University Press, Oxford.

Imran, M.K., Ilyas, M. and Fatima, T. (2017), "Achieving organizational performance through knowledge management capabilities: mediating role of organizational learning", Pakistan Journal of Commerce and Social Sciences, Vol. 11 No. 1, pp. 106-125.

Johansson, A.E., Raddats, C. and Witell, L. (2019), "The role of customer knowledge development for incremental and radical service innovation in servitized manufacturers", Journal of Business Research, Vol. 98, pp. 328-338.

Joe, T. and Hull, F.M. (Eds) (2003), Service Innovation: Organizational Responses to Technological Opportunities and Market Imperatives, World Scientific, Vol. 9.

Lee, S., Kim, B.G. and Kim, H. (2012), "An integrated view of knowledge management for performance", Journal of Knowledge Management, Vol. 16 No. 2, pp. 183-203.

Li, L., Li, G., Yang, X. and Yang, Z. (2019), "Pursuing superior performance of service innovation through improved corporate social responsibility: from a knowledge acquisition perspective", Asia Pacific Journal of Marketing and Logistics, Vol. 31 No. 4, pp. 925-943.

Lusch, R.F. and Nambisan, S. (2015), "Service innovation: a service-dominant logic perspective", MIS Quarterly, Vol. 39 No. 1, pp. 155-176.

Mahr, D., Lievens, A. and Blazevic, V. (2014), "The value of customer cocreated knowledge during the innovation process", Journal of Product Innovation Management, Vol. 31 No. 3, pp. 599-615.

Mario, S., Gianfranco, W. and Heiner, E. (2018), "Customer interaction and innovation in hybrid offerings: investigating moderation and mediation effects for goods and services innovation", Journal of Service Research, Vol. 21 No. 1, pp. 119-134.

Melton, H.L. and Hartline, M.D. (2010), "Customer and frontline employee influence on new service development performance”, Journal of Services Research, Vol. 13 No. 4, pp. 411-425.

Mishra, B. and Bhaskar, A.U. (2011), "Knowledge management process in two learning organisations", Journal of Knowledge Management, Vol. 15 No. 2, pp. 344-359. 
Moon, M.A., Khalid, M.J., Awan, H.M., Attiq, S., Rasool, H. and Kiran, M. (2017), “Consumer's perceptions of website's utilitarian and hedonic attributes and online purchase intentions: a cognitive-affective attitude approach", Spanish Journal of Marketing-ESIC, Vol. 21 No. 2, pp. $73-88$.

Morgan, T., Obal, M. and Anokhin, S. (2018), "Customer participation and new product performance: towards the understanding of the mechanisms and key contingencies", Research Policy, Vol. 47 No. 2, pp. 498-510.

Morgan, T., Anokhin, S.A. and Wincent, J. (2019), "New service development by manufacturing firms: effects of customer participation under environmental contingencies", Journal of Business Research, Vol. 104, pp. 497-505.

Ngo, L.V. and O'cass, A. (2013), "Innovation and business success: the mediating role of customer participation", Journal of Business Research, Vol. 66 No. 8, pp. 1134-1142.

Nunnally, J.C. (1978), Psychometric Theory, McGraw-Hill, New York, NY.

Paswan, A., D'Souza, D. and Zolfagharian, M. (2009), "Toward a contextually anchored service innovation typology", Decision Sciences, Vol. 40 No. 3, pp. 513-540.

Pavlou, P.A., Liang, H. and Xue, Y. (2007), "Understanding and mitigating uncertainty in online exchange relationships: a principal-agent perspective", Management Information System Quarterly, Vol. 31 No. 1, pp. 105-136.

Podsakoff, P.M., MacKenzie, S.B., Lee, J.Y. and Podsakoff, N.P. (2003), "Common method biases in behavioral research: a critical review of the literature and recommended remedies", Journal of Applied Psychology, Vol. 885 No. 879, pp. 10-1037.

Preacher, K.J. and Hayes, A.F. (2008), "Asymptotic and resampling strategies for assessing and comparing indirect effects in multiple mediator models", Behavior Research Methods, Vol. 40 No. 3, pp. 879-891.

Rahman, A.A., Ng, S.I., Sambasivan, M. and Wong, F. (2013), "Training and organizational effectiveness: moderating role of knowledge management process", European Journal of Training and Development, Vol. 37 No. 5, pp. 472-488.

Salunke, S., Weerawardena, J. and Mccoll-Kennedy, J.R. (2013), "Competing through service innovation: the role of bricolage and entrepreneurship in project-oriented firms", Journal of Business Research, Vol. 66 No. 8, pp. 1085-1097.

Sawy, O.A.E., Malhotra, A., Gosain, S. and Young, K.M. (1999), "IT-intensive value innovation in the electronic economy: insights from Marshall Industries", MIS Quarterly, Vol. 23 No. 3, pp. 305-335.

Schaarschmidt, M., Walsh, G. and Evanschitzky, H. (2018), "Customer interaction and innovation in hybrid offerings: investigating moderation and mediation effects for goods and services innovation”, Journal of Service Research, Vol. 21 No. 1, pp. 119-134.

Schreier, M., Fuchs, C. and Dahl, D.W. (2012), "The innovation effect of user design: exploring consumers' innovation perceptions of firms selling products designed by users", Journal of Marketing, Vol. 76 No. 5, pp. 18-32.

Schumpeter, J. (1942), Capitalism, Socialism and Democracy, Harper Perennial, New York.

Son, J. and Jin, B.E. (2019), "When do high prices lead to purchase intention? Testing two layers of moderation effects", Asia Pacific Journal of Marketing and Logistics, Vol. 31 No. 5, pp. 1516-1531.

Storey, C. and Kahn, K.B. (2010), "The role of knowledge management strategies and task knowledge in stimulating service innovation", Journal of Service Research, Vol. 13 No. 4, pp. 397-410.

Storey, C. and Kelly, D. (2001), "Measuring the performance of new service development activities", Service Industries Journal, Vol. 21 No. 2, pp. 71-90. 
Sun, Y., Liu, J. and Ding, Y. (2020), Analysis of the Relationship between Open Innovation, Knowledge Management Capability and Dual Innovation, Technology Analysis and Strategic Management, Vol. 32 No. 1, pp. 15-28.

Ting, D.H., Abbasi, A.Z. and Ahmed, S. (2020), "Examining the mediating role of social interactivity between customer engagement and brand loyalty", Asia Pacific Journal of Marketing and Logistics, Vol. 33 No. 5, pp. 1139-1158.

Tiwana, A. (2000), The Knowledge Management Toolkit, Prentice Hall PTR, Upper Saddle River, NJ.

Toivonen, M. and Tuominen, T. (2009), "Emergence of innovations in services", The Service Industries Journal, Vol. 29 No. 7, pp. 887-902.

Trischler, J., Pervan, S.J., Kelly, S.J. and Scott, D.R. (2018), "The value of codesign: the effect of customer involvement in service design teams", Journal of Service Research, Vol. 21 No. 1, pp. 75-100.

Tseng, S.M. and Lee, P.S. (2014), "The effect of knowledge management capability and dynamic capability on organizational performance", Journal of Enterprise Information Management, Vol. 27 No. 2, pp. 158-179.

Vakulenko, Y., Shams, P., Hellström, D. and Hjort, K. (2019), "Service innovation in e-commerce last mile delivery: mapping the e-customer journey", Journal of Business Research, Vol. 101, pp. 461-468.

Vargo, S.L. and Lusch, R.F. (2008), "Service-dominant logic: continuing the evolution”, Journal of the Academy of Marketing Science, Vol. 36 No. 1, pp. 1-10.

Wang, J. and Liu, L. (2019), "Study on the mechanism of customers' participation in knowledge sharing”, Expert Systems, Vol. 36 No. 5, pp. 1-13.

Wang, L., Jin, J.L., Zhou, K.Z., Li, C.B. and Yin, E. (2020), "Does customer participation hurt new product development performance? Customer role, product newness, and conflict", Journal of Business Research, Vol. 109, pp. 246-259.

Watson, R., Wilson, H.N., Smart, P. and Macdonald, E.K. (2018), "Harnessing difference: a capabilitybased framework for stakeholder engagement in environmental innovation", Journal of Product Innovation Management, Vol. 35 No. 2, pp. 254-279.

Weerawardena, J., Salunke, S., Knight, G., Mort, G.S. and Liesch, P.W. (2019), “The learning subsystem interplay in service innovation in born global service firm internationalization", Industrial Marketing Management, Vol. 89, pp. 181-195.

Witell, L., Snyder, H., Gustafsson, A., Fombelle, P. and Kristensson, P. (2016), "Defining service innovation: a review and synthesis", Journal of Business Research, Vol. 69 No. 8, pp. 2863-2872.

Witell, L., Gebauer, H., Jaakkola, E., Hammedi, W., Patricio, L. and Perks, H. (2017), "A bricolage perspective on service innovation", Journal of Business Research, Vol. 79, pp. 290-298.

$\mathrm{Wu}, \mathrm{Y}$. (2014), "Influence of network competence on innovation competence of star-ups: the mediating effect of knowledge management”, Studies in Science of Science, Vol. 32 No. 8, pp. 1218-1226, (In Chinese).

Yoo, Y., Boland, R.J., Lyytinen, K. and Majchrzak, A. (2012), "Organizing for innovation in the digitized world", Organization Science, Vol. 23 No. 5, pp. 1398-1408.

Yu, M.C. (2017), "Customer participation and project performance: a moderated-mediation examination”, Project Management Journal, Vol. 48 No. 4, pp. 8-21.

\section{Further reading}

Foss, N.J. (1996), "Knowledge-based approaches to the theory of the firm: some critical comments", Organization Science, Vol. 7 No. 5, pp. 470-476.

Håkanson, L. (2010), "The firm as an epistemic community: the knowledge-based view revisited", Industrial and Corporate Change, Vol. 19 No. 6, pp. 1801-1828.

Service
innovation in
the digital age

\section{$-$}


Salancik, G.R. and Jeffrey, P. (1978), "A social information processing approach to job attitudes and task design”, Administrative Science Quarterly, Vol. 23, pp. 224-253.

Song, L.F. (2016), “Analysis on China's e-commerce strategy: a case study of Alibaba”, E-commerce Study, Vol. 14 No. 4, pp. 39-55.

\section{About the authors}

Xiaohua Xin is a Ph.D. candidate at the School of Management, Northwestern Polytechnical University. Her research is mainly focused on service innovation and innovation ecosystem. Xiaohua Xin is the corresponding author and can be contacted at: xinxiaohua@mail.nwpu.edu.cn

Xiaoming Miao is a professor at the School of Management, Northwestern Polytechnical University. His research is mainly focused on innovation management and industrial economy.

Qian Chen is a postdoc in the Department of Machine design, ITM, KTH Royal Institute of Technology. Her research interests are front end of innovation, sustainable innovation.

Tiantian Shang is a lecturer in School of Economics and Management at Xian Technological University. Her research is mainly focused on innovation management.

For instructions on how to order reprints of this article, please visit our website: www.emeraldgrouppublishing.com/licensing/reprints.htm Or contact us for further details: permissions@emeraldinsight.com 